Наде Костадиновска-Спасеновска

\title{
ОТКАЖУВАЊЕ ОД НАСЛЕДСТВОТО ОД ЖЕНСКИ АСПЕКТ (ПРИЧИНИ, ПОСЛЕДИЦИ, ЧУВСТВА)
}

\begin{abstract}
Апстракт: Во поглед на наследувањето, жената секогаш немала позиција во која по сите закони се почитувале нејзините права, туку спротивно на тоа, била на границата на маргинализираноста од средината во која живеела. Но, дали вистинската причина за таа маргинализираност лежи само во опкружувањето или пак и жената е одговорна, е дискутабилно прашање. Долго живеејќи во една рамка во која била подредена и ограничена во своите барања и потреби, таа ги прифатила околностите како „нормални“, без можност да ги доведе во прашање. Во овој момент не го земам предвид сето она што жената потајно може да го направи за да ја постигне својата цел. Прашањето на кое би сакала да дадам одговор е дали жената чувствува(ла) дека е загрозена на било кој начин од процесот на наследување.
\end{abstract}

Клучни зборови: наследување, жена, чувства, брат, сестра.

Во текот на моето истражување, кое се одвиваше во Скопскиот Регион (Горни Села и населбите во општина Аеродром), наидов на различни ставови, кои го привлекоа моето внимание. Едно од нив е немањето желба да се случат или пак уште потешко да се иницираат промени во ова поле во корист на жените. Ова особено се јавува во руралните средини кај жените во поодминатите години, кои веќе треба да го дадат својот имот (се мисли на имот од сопругот) во наследство на своите деца. Следејќи некоја „логика“, ако самите сме преживеале некоја неправда во младоста, би сакале да го промениме тоа како жени, за во иднина и нашите ќерки да не ја чувствуваат истата неправда. Но, во овој случај оваа логика во практиката се покажа како неточна. Моите соговорнички, на ова, не гледаат на таков начин. Тие сметаат дека тоа така треба да биде, како за нив, така и за своите керки. Иако се свесни за болката што им ја причинуваат, за оваа група жени е побитно да се следи традицијата. Ова е збунувачки бидејќи кај сите соговорнички се јавува чувство на тага за родниот дом, за стоката што ја чувале, за нивите што ги работеле, жал за трошните sидови од родителскиот дом во кој пораснале, вложувале, а не добиле ништо за возврат, ништо за спомен. Присутна е и болката кај сите нив и за тоа спомнуваат со тага во очите. И покрај ова, тие сметаат дека машкото е оној кој е наследник. Жените, иако свесни за неправдата што ја имаат, сметаат дека така треба да биде, иако жалат што се неправедни кон своите ќерки. Сепак, во минатото, таткото бил тој што имал главна улога во оставинската постапка и најчесто бил оставител. Дури и кога жената, како сопруга, го имала имотот, таа сепак ја продолжувала традицијата, односно ја почитувала желбата на мажот да го даде наследството на своите синови. Иако како имател на наследство се јавува жената како сопруга, таа не го чувствувала тој имот за свој, бидејќи најчесто сопругот го 
добивал имотот по пат на наследство. Можеби поради тоа жената немала желба да иницира промени во овој дел, бидејќи она што го добивала таа во наследство - мајковината, таа го делела на сите деца, не правејќи разлика во полот. Дури и на жената да ѝ пречела ваквата родова поставеност во наследувањето, таа ретко кога имала имот што бил лично нејзин за да може да го промени сето тоа. Обичајното наследно право налага да се има машки потомок, кој ќе ја продолжи лозата и ќе ги дочува своите родители: „На пример, популарна изрека при раѓање на машко дете е: Cе смеела стреата за машко дете оти била отворена куќата, што значи дека со раѓањето на машко дете, родителите добиваат извесна сигурност во староста, според патрилокалниот принцип на живеење“ (Ашталковска, 2005, 176). И другата позната поговорка, која е во обратен концепт, каде што cmpeume плачат, наместо да се смеат, кога се раѓа женско дете, јасно покажува во која насока се движело значењето на машкото, а во која - значењето на женското дете. Така и биле третирани од своите родители во поглед на наследувањето.

Синот бил оној што го наследува имотот, презимето, односно оној од кој се очекува да го продолжи родот. Додека, пак, керката е таа од која се очекува да се откаже од наследството во корист на братот, а со тоа целиот имот да остане во семејството кај синот наследник. Иако ќерката има законско право на наследство подеднакво со синот, сепак кај нас најчесто преовладува обичајното право, односно жената да се откаже од својот дел во името на братот или децата по желба на своите родители или сопругот. Во минатото, па и денес во помал обем, со тоа што родителите го давале имотот само на синот, не само што ѝ го скратуваат правото на ќерката да има дел од имотот кој ѝ припаѓа според законот, туку ѝ го скратуваат и правото на избор со тоа што очекуваат таа да се откаже од делот. Тука најчесто без своја желба жената се откажува(ла) од наследството. Според законот, при оставинска постапка таа, како една од наследниците од прв ред на оставителот, треба задолжително да се изјасни дали го прифаќа или не го прифаќа делот од имотот, кој, според законските регулативи, ѝ следува. Но, најчесто таа се откажува. Всушност, во процедурата за оставинска постапка најчесто присуствува само формално да се зачува законската процедура. Додека пак во минатото кога законите не биле толку ригорозни како што можеби се денес, жената не била ни известувана за оставинската постапка, туку едноставно, според традиционалните сфаќњњ, било во ред таа да биде изоставена.

Како се чувствувала жената без разлика за кој семеен статус станува збор, немало значење. Дали пак имала желба да се изјасни, според нејзините потреби во врска со ова прашање, не било предмет на разговор. Освен сувопарниот начин на кој се одвивал процесот на наследување, мене ме интересираа чувствата и желбите на жените кои ги имале тие, на оваа тема. Па така, во текот на истражувањето кај речиси сите мои соговорнички наидов на чувство на гнев, можеби и омраза кон сопствениот татко како главен причинител за нивната состојба кога е во прашање наследувањето: „Никако... лошо... отфрлено дете, непочитувано...“ (Соговорничка: Савеска Јованка). ${ }^{1}$

\footnotetext{
${ }^{1}$ Податоците за соговорниците се дадени на крајот.
} 
Тие се свесни за состојбата во која биле, особено како керки, кога можеби се очекува(ло) и поголема заштита и поддршка од родителите. Тие не го почувствувале тоа. Родителската грижа за керките била ограничувачка, а нејзината подготовка за туѓa куќа, која се правела од рана возраст, можеби ги натерало и родителите својата енергија повеќе да ја насочат кон синот како свој, а ќерката да ја третираат како туѓа: „Наклонетоста и симпатијата на родителите спрема едно дете најчесто произлегува од традиционалните сфаќања за улогата и местото на детето во семејството со оглед на неговата полова и старосна припадност. Поради тоа синовите, односно браќата, имаат голема улога и права во семејството, особено при наследувањето, во однос на сестрата, ќерката“ (Ђорђевић, 2001, 68).

Инвестирањето во градење на имот и заштита на семејните добра, придонесуваат грижата да се насочува кон својата куќа во која останува синот, а не кон туѓата во која оди ќерката. Па така и грижата кон ќерката се намалува. Порано, како некој вид обештетување бил чеизот. Било несфатливо на ќерката да се даде дел од куќа бидејќи таа ќе оди во друга куќа. Несфатливо можеби за родителите, кои сакале својата куќа што ја граделе макотрпно да остане цела и во неа да живее синот (синовите), кој (кои) останува (остануваат) тука, за да не згасне огништето. Ова можеби е и причина поради која родителите очекуваат да се откаже керката од својот дел. Но, ова можеби логично објаснување не важело кај ќерките. Тие како што кажав претходно, во голем број случаи се чувствувале отфрлени, незаштитени од родителите: „Такво било времето, такви биле татковците, сѐ за машките, за синовите, а ќерките кој ги шиша... Велеле, туѓа стреа се тие, таму нека бараат“ (Соговорник: Савеска Јованка).

Најчесто вината ја гледаат во таткото, како глава и столб на патријархалното семејство. Додека пак кон мајката негуваат чувства на нежност, љубов, знаејќи дека таа, како жена, е во иста положба како и тие и дека не е моќна пред гласот на таткото и на колективот. Па, затоа, говорат со тага и солзи за домот, за мајката која ги одгледала и сакаат да имаат дел од тој имот, каде што се родени, макар и некоја нива, а не семејна куќа, за да се сеќаваат на топлиот дом, на мајката, на детството. „Жените, семејниот имот или подобро речено имотот од своите родители, го доживуваат како социјално добро. Тие не мислат дека со тоа што наследиле дел од тој имот ја подобриле својата материјална состојба“ (Борђевић, 2005, 218). Бидејќи овие жени го сметаат родното огниште повеќе за свое, отколку оние огништа каде што одат и го поминуваат остатокот од животот. Како што низ солзи говореше една моја соговорничка: „Но барем од мајка ми нешто да ми останеше, да имав свое“ (Соговорник: Грујоска Божа). Во минатото ќерката се сметала за „туѓа“ и се одело до тој степен што откако ќе се омажела немала право да бара ништо, ниту имот, ниту некаква материјална помош: „Кога ке се омажат, нема назад враќање, имот да бараат“ (Соговорник: Китаноска Цанка).

Најчесто со родителите останувал најмалиот син. Во случај кога не живееле во заедница, сепак на некој од синовите му било обврска да ги дочува. Но, најчесто како што кажуваат моите соговорнички, во реалноста не било така. Чести биле повиците за помош кон ќерките, за да ги чуваат на 
старост, иако не им дале имот, сепак сметаат дека љубовта на ќерката е поголема кон нив, па и поради тоа, а можеби и немајќк друг избор, отфрлени од синот, бараат помош од ќерката. Но, не секогаш ќерките им излегувале во пресрет. А како главна причина за ова е тоа што се чувствувале отфрлено од своите родители, кои сега бараат помош од нив: „Само за синојте, а после ела ќерко ми е лошо, запери ми ги аливчињава. Барај си го како сакаш, нему си му давала“ (Соговорник: Вида).

Овде можеме да забележиме дека станува збор за нарушени семејни односи, на релација ќерка - родители. Иако можеби секогаш таа не го кажува јавно тоа, но во неа потајно тлее чувство на незадоволство. Не секогаш јавно говорат за нивните односи со родителите, бидејќи од нив се очекува да бидат послушни ќерки, па поради тоа незадоволството лежи во самите нив и тоа_не е аргумент со кој ги рефлектираат своите односи кон родителите. Тие знаат дека формално гледано не би требало да чувствуваат обврска да им помогнат во староста бидејќи за тоа го задолжиле синот. Но, ретко одбивале, а и ретко кога јавно зборувале за тоа, освен, можеби кога се во поодминати години. Тие сметале дека треба да ги одржуваат семејните односи ненарушени бидејќ тие односи биле особено важни во минатото, при што било битно да се сочуваат особено за очите на јавноста. За да се зачуваат овие релации, односно родителите и понатаму да бидат во добри односи со ќерката, се внимавало да не се навредат тие. Поради тоа, таа се откажувала од наследството според нивната желба, особено желбата на таткото, имотот да оди кај наследникот синот: „Сестрите се откажаа, зошто татко им сакал на машките да остане“ (Соговорник: Костадиновска Верка).

Родителите за да направат некоја изедначеност во поглед на наследувањето, како што веќе објаснив претходно, на ќерките им давале чеиз, што на некој начин претставува ослободување на сопствената свест и совест на родителот дека и на ќерките нешто им дале и не ги оставиле туку така како да не се нивни деца, туку грижата ја исполниле во целост бидејќк, во согласност со обичаите, на тој начин биле обезбедени и тие. Од друга страна, пак, ја обврзуваат ќерката да не бара ништо. Иако чеизот не може да се спореди со: семејната куќа, стоката, нивите, покуќнината, алатот и другото што го добивал синот, сепак тие (ќерките) го прифатиле тоа. Затоа често во разговорите со соговорничките наидував на изразите: „па чеиз ми дадоа“, „свадба ми направија“, „мебел ми купија“ и сл., кои ги користат во смисла дека немаат повеќе права да бараат ништо и затоа од нив се очекува да се откажат од наследството. А за да се зачуваат семејните односи, тие го прават и тоа.

Воспитувањето на децата во минатото, па во некои средини и денес, е во насока на следење на традицијата, односно следење на вредностите што ги налага патријархалното семејство. Во нив женското дете се учело на: послушност, покорност кон постарите членови на семејството - особено кон машките, без разлика на возраста. Женските деца ги воспитувале да го прифатат семејството и начинот на неговото функционирање онака како што e, без да размислуваат дали е правилно или не е правилно тоа, да бидат молчеливи, да не го повишуваат својот глас, да не бараат промени, туку да ги 
следат обичајните вредности. Особено женските деца биле учени на вреднување и на чување на семејните односи и на почитување на семејните обичаи и традиција, бидејќи семејството било и примарна функција на жената. Вака воспитувани, женските деца продолжиле со таа традиција со која израснале, следејќи ги вредностите, некои трпејќи ги на својата кожа, а други пак следејќи ги со задоволство, но како и да е, сите ги пренесувале и на своите деца. Обратно од ова, машкото дете било воспитувано дека е поважно од женското: „Па тие се машки“ (Соговорник: Костадиновска Верка). Овој израз би требало да ни каже сѐ. Во него се гледа важноста што им била придавана и пиедесталот на кој биле поставувани.

Тенденцијата на родителите да постои таа разлика меѓу брат и сестра и нивното различно вреднување, од нивна страна, придонело да се појави јаз на вреднување и меѓу децата. Така воспитани, сестрите не сметале дека се обесправени во тој поглед и дека не се рамноправни, бидејќ така биле воспитувани, за друго и не знаеле. Сестрите биле воспитувани да ги слушаат, да ги почитуваат и да се грижат за браќата, можеби и затоа се грижат да ги сочуваат добрите семејни односи со братот, па дури и да се откажат од семејното наследство поради тоа. Тоа било уште една од причините поради која жените, како сестри, се откажувале од наследството.

Оваа причина има два аспекти. Првиот е тоа што така биле воспитувани. Тежнеењето на родителите кон синот, како наследник, зашто бил подготвуван од рана возраст, придонело ќерката да расте во тој дух, каде што братот е наследникот. Како дете, за неа тоа било нормално штом родителите така им кажувале. Како што растела, повторно така воспитувана и не барала причина зошто би било поинаку. Што значи таа веќе го прифатила братот за наследник и немала причина да го смени тоа подоцна, кога дошло време за наследување.

Вториот дел е тоа што сестрата се трудела да ги зачува добрите семејни односи со братот за кои се стремеле и родителите, особено мајката, но поради наследството можеле да бидат нарушени. Како што кажуваат моите соговорнички: „Просто неќам брат и сестра да се караат, да се неќат“ (Соговорник: Грујоска Божа); „Очиве мои ќе замижат, а тие ќе се караат, а вака оди си, едната има кај свекрвата, другата овде“ (Соговорник: Вида).

Затоа, поради семејните односи, а особено поради одржување на добрите односи на релација брат - сестра и обратно, тие сметале дека е најдобро сестрата да не се меша во наследството, туку да го остави на братот, а таа да ја гради својата иднина во куќата на мажот. Ова размислување повторно е поттикнато од околината, а е наметнато низ процесот на воспитување, бидејќи доколку децата бидат родово воспитувани рамноправно, не би требало да постојат лоши односи на релација брат - сестра и обратно, бидејќи така би биле еднакви за сѐ, па и за наследување. Со тоа што братот бил воспитуван како наследник, тој очекувал тоа и да биде. За него не е сфатливо сестрата да земе дел од наследството за кое уште од најрана возраст му се кажувало дека е негово. Вака воспитувани децата со подредени улоги, желби, па и можности, имале и одредени, веќе оформени сфаќања, концепирани од традицијата, без желба за промени, кои придонеле да се прават и половите разлики. Братот, во овој поглед, не можам да кажам дека 
сака да ѝ наштети на сестрата или пак дека помалку ја сака и помалку се грижи за неа, иако често се сретнува дека љубовта на сестрата кон братот е поголема, како во народното творештво, така и меѓу моите соговорнички: „Братот може да ја неќи, но сестрата никој пат“ (Соговорник: Грујоска Божа).

Сестринската љубов е опеана и во многу песни, кои се дел од македонскиот фолклор:

„Тогај викна Јана: О леле до бога!

Кога немам брате, нејќу ни да живја!

Речта не дорече в часот Јана падна,

В часот Јана падна падна и си зајде.“

(Миладиновци, 1962, 305).

Братот (браќата) смета дека наследството му припаѓа нему и дека секој оној кој сака да му го земе, сака да му наштети: „Ако му земеш на братот ќе те мрази довека, ако се направиш брат и да му земеш, ќе те мрази цел живот ако му се мешаш во имотот“ (Соговорник: Савеска Јованка). Со оглед на вака поставени работите, особено во минатото, на сестрите не им преостанувало ништо, туку да го направат она што се очекувало од нив, да се откажат од наследството во корист на братот.

Сестринската љубов е голема и тие (сестрите) не сакаат да влегуваат во конфликт со братот и да објаснуваат дека и тие имаат право на тој имот бидејќи, како што кажуваат моите соговорнички, и тие придонесувале во куќата (ја граделе заедно со родителите и со братот; заедно работеле на нивите) и имаат подеднакво право на имотот. Но, сепак, во минатото, без разлика какви и да биле чувствата на сестрата, колку и да тажела и копнеела по родителскиот дом, таа сепак се откажувала од имотот: „Мене имот не ми требит, мене ми требит љубовта со братот да ја имам и фамилијата“ (Соговорник: Трајковска Благујна).

Освен сестринската љубов, како чест мотив во песните создадени од македонскиот народ, а инспирирани од секојдневието, ја среќаваме и пожртвуваноста на сестрата кон братот, исто како и во претходниот исказ на мојата соговорничка, каде што освен сестринската љубов јасно можеме да ја забележиме и токму таа сестринска пожртвуваност. Ист мотив со овие две сестрински особини забележуваме и во песната „Стојан и сестра Шенгјуфа“:

„Сегде си таа шетала,

Црни си очи заложвит, Бело си лице продаат, Туку да брата откупит, От пуста, темна з'ндана“.

(Миладиновци, 1962, 179). 
Постапката што ја прави сестрата, откажувајќи се од имотот, се вреднувала во општеството и таа била почитувана од братот, од родителите и од поширокото семејство бидејќи ги почитувала обичаите, a co тоа и семејството и го оставила имотот на братот. Сестрата се откажува од имотот во корист на братот не барајќи ништо освен желба да ја чува и гледа нивната мајка на старост како што доликува, но како што споменав и претходно, често не било така: „Само мајка да ја чуваат, ама не беше така“ (Соговорник: Грујоска Божа).

Освен да се зачуваат добрите семејни односи со братот, сестрата морала да ги зачува и добрите семејни односи со снаата, која била повеќе почитувана како жена на братот од сестрата. Таа во куќата имала повеќе наследни права отколку сестрата во родната куќа. Жената можела да добие наследство како сопруга, преку својот сопруг. Па, поради тоа, на неа ѝ било наложено да се грижи за куќата и да биде новиот потенцијален наследник на истата куќа во која сестрата го изгубила правото на наследство. Иако станува збор за истата куќа што најчесто сестрата ја чувствувала за своја, иако со мажењето тоа се сменува и куќата повеќе не е нејзина, сепак чувствата кон неа остануваат. Тука снаата (мислам на односот золва 'сестра на мажот' - снаа) веќе се покажува како жена со повеќе права на таа куќа, а не золвата и најчесто се труди да даде до знаење дека тоа е така. Почитта на оваа релација постои, но имотот се знае дека е на братот, па тука и неговата сопруга се јавува како строг бранител на тој имот: „Готово вика... почитување ќе имаш, кога сакаш дојди за ручек ќе имаш, ама више си се омажила и да бараш право немаш“ (Согов. Серафимовска Драгана). Золвата добива почитување од снаата бидејќи таа се откажала од имотот како што и доликува, според обичајните вредности.

Често, браќата, грижејќи се за сестрите, сакале да им возвратат со нешто, најчесто парично, симболично, без разлика дали се работи за пари од продадена стока или нешто друго, но најчесто биле спречувани од нивните сопруги, со истото оправдување дека сестрата откако ќе се омажи нема право на ништо.

Овде постојано наидуваме на нелогичност бидејќи и снаата се соочува со истото од нејзината родна страна и најверојатно поради чувство на солидарност би требало да биде попустлива кога е во прашање нејзината золва. Но, во реалноста не е така. Таа, следејќи го својот пример и повторно така воспитувана, смета дека е исправно золвата да не добие ништо откако ке се омажи, исто како што не добила и таа. Дури станува егоистички настроена кон золвата, бидејќи кон неа не негува чувства на роднинска блискост, туку само почит и не иे пречи да влезе во конфликт за да го одбрани она што смета дека му припаѓa на нејзиниот маж, а оттаму - на неа, или уште појаката припадност за една мајка - на нејзините деца. Таа, па и нејзиниот маж, ја гледаат золвата како туѓинец што сака да им го земе имотот. Но, бидејќи нејзиниот маж бил близок со својата сестра, тој сака да ѝ помогне и да ѝ даде дел од она што му припаднало нему, како некој надомест, бидејќи таа се откажала. Такви случаи има многу, но често сестрите и тоа не го прифаќаат, а главно поради тие семејни односи, како и поради околината, бидејќи ако зела надокнада ќе биде исто како да зела дел. Речиси секогаш жената на братот 
играла голема улога во ваквите случаи поради тоа сестрата не сакала да ги наруши односите со снаата и со братот, но и односите меѓу нив двајца. Затоа говорат и моите соговорнички: „Сакаме тебе да ти го дадеме, тие ме нудеа и за беспари“ (Соговорник: Трајковска Благујна); „Постариот брат рече да им дадеме по сто марки“ (Соговорник: Китановска Цанка). Но, најчесто за да не дојдат во конфликт со своите жени, тоа не го исполнувале, или пак сестрите не земале, за да не им наштетат на браќата во нивниот семеен однос со жените: „Ние кај братот не се мешаме, снаата и онака не нѐ сака“ (Соговорник: Грујоска Божа).

Сестрите покрај ваквиот однос што го имале кон братот, нивната љубов, грижа, сепак кај нив се јавува чувство на запоставеност од браќата, лутина кон нив, не во смисла дека не добиле дел од наследството, туку лутина поради тоа што тие, сестрите, останале на зборот, се откажале од имотот, а најчесто браќата не го исполниле она на што се обврзале. Тоа најчесто е негрижата кон нивните родители на старост, особено на негрижата кон мајката. Најчесто поради ова, денес, кога тие генерации жени се во поодминати години, се каат што се откажале од имотот и сметаат дека имале право на дел исто колку и братот. Друга причина поради која тие генерации жени сметаат дека не требале да се откажат од имотот е невозвратената почит и грижа од братот, поради тоа што, како што кажуваат моите соговорнички, и тие придонесувале за градење на куќата, со свои пари што ги заработувале и со свои раце паралелно работеле со братот: „Работев по бавчи, по планиниве и мои што имав не ми дадоа“ (Соговорник: Савеска Јованка); „Зошто стоката ја продадоа и мие ја чувавме“ (Соговорник: Китановска Цанка); „И работев... Брат ми ми вика, сестро дрва немаме... јас, брату сега ќе купиме и су работела сѐ, куќата ја направивме, врати, прозори, сѐ ја““ (Соговорник: Серафимовска Драгана).

Кај овие генерации жени се појавува свесноста за своето, за својот труд, и иако велат дека „така било“, „така функционирале работите“, сепак сметаат дека не се ништо помалку вредни од своите браќа, и дека колку и да е голема нивната љубов кон братот, сепак таа релација треба да биде двонасочна, па и тие да ја добиваат потребната помош од нив, односно, собено да може сестрата, која вложувала во куќата паралелно со него, да побара тоа што смета дека ѝ следува. Но, најчесто и тогаш биле одбивани поради истата причина: „Боли... Јас една нива побарав, куќичка да направам - не ми даде“ (Соговорник: Серафимовска Драгана).

Браќата, можеби повеќето свесни за грижата и почитта што ја добиваат од сестрите, знаат дека тоа што им го возвраќаат тие е минимално, но кај нив е потешко да се искорени, пред се́, да се надмине сфаќањето за „машкоста“, па затоа ретко кој од мажите, особено од постарите генерации, сака да се стави на исто ниво со сестрата, иако ја знаат сестринската пожртвуваност, како што потенцираше една моја соговорничка во разговорот што го водевме на темава: „Брат ми до последен ден златна сестро ме викаше“ (Соговорник: Серафимовска Драгана).

Постарите генерации жени, кои што живеат во урбаните средини во пределов што го истражував, во денешно време им се променети размислувањата во врска со оваа тема. Голем дел од нив сметаат дека треба да 
дадат дел од имотот и на ќерките, а некои веќе го направиле тоа. Но, тие што живеат во руралните средини продолжуваат и понатаму да ги негуваат размислувањата предводени од традицијата иако, на своја кожа ја имаат почувствувано неправдата и за тоа јавно говорат. Сметаат дека треба да продолжат онака како што се навикнати и научени од нивните предци и не се подготвени за промени. Сепак, бројот на жени, кои се откажуваат од имотот во корист на братот е голем: „Иако според законските прописи, женските деца имаат подеднакво право на наследство од своите родители како и машките деца, сепак и денес е многу застапено сестрата да се откаже од правото на наследство во корист на братот, а како главна причина за тоа се наведува да останат сродничките односи ненарушени“ (Петреска, 2005, 304).

Потребно е време и промена на генерации да се промени, пред сѐ, размислувањето на луѓето на оваа тема, па потоа и да се применува, секако етапно, со долги и бавни чекори. Во разговорите што ги имав со помладите генерации жени од истиот регион во кој истражував, се забележува разлика во начинот на размислување и себевреднување кај жените, кои се млади мајки, па и тие по нив, кои се студенти денес. Помладите генерации сметаат дека жената треба да има исто наследно право како и мажот. Повеќето од нив, како главен виновник за начинот на наследување според обичајното право го посочуваат воспитувањето. Сметаат дека во иднина мајките, како примарни воспитувачи, а потоа и наставниците во воспитно-образовниот процес, треба да ги третираат подеднакво машките и женските деца. Сѐ додека постои стариот начин на воспитување во семејството, тешко дека ќе може да се промени овој процес, кој, според младите генерации жени, е дискриминирачки.

Како што разговарав со најмладите генерации жени, родени во деведесетите_години на дваесетиот век, размислувањата се сосема поинакви од оние на постарите генерации жени, кои се нивни баби. Кај нив наидов на јасно кажување, без страв, дека некој од околината погрешно ќе ги разбере. Сѐ уште живеејќи во средина, каде што старите генерации се доселеници од руралните средини, тие наидуваат на пречки, во смисла на озборување од околината и негодување, но тоа за нив не е важно. Преовладува чувството на свесност за себе, како жена, и за своите права. Иако голем број од нив не го познаваат во целост законот, знаат дека според логиката на нештата и тие имаат исти права како и нивните браќа и дека во никој случај не можат да бидат помалку вреднувани поради полот: „Ние сме деца на исти родители, колку што е он дете на моите родители - толку сум и јас“ (Соговорник: Костадиновска Ана). Тие сметаат дека треба да бидат рамноправни во наследувањето и дека со тоа не му наштетуваат на братот, бидејќи не му го земаат делот што нему му припаѓa, туку дека си го земаат својот дел: „Не сметам дека му наштетувам, не барам повеќе... колку ќе имам јас - толку и тој“ (Соговорник: Угриновска Наташа).

Според нив, љубовта и грижата на релација сестра - брат и обратно, треба да постои и треба да се негува уште од мала возраст, но да не се прави разлика меѓу грижата и правата што ги имаат, како деца на исти родители. Да се воспитуваат децата, особено братот, дека сестрата не е туѓинец, туку некој 
што ги има истите права како и тој и поделбата на имотот да не значи конфликт меѓу нив, туку делба на имот, кој подеднакво им следува. Како најчеста причина, која се наведува дека треба да имаат дел од имотот од родителите, освен примарната, е дека не знаат каде ги носи животот и дека дури и во моментот некој од нив да нема потреба од имот, во иднина можеби нема да биде така: „Да имам некој свој дел, да можам нешто да си изградам, да имам на кого да се потпрам, кога нешто лошо ќе се случи“ (Соговорник: Угриновска Наташа); „Не знаеме животот кај ќе нѐ нанесе, можеби утре ќе се разведам, не сакам да останам како некои на улица, а притоа имам услови, кои можат моите родители да ми ги пружат“ (Соговорник: Костадиновска Ана).

Кај младите генерации жени се јавува момент поразличен од оној кај постарите генерации, кои зборуваат со носталгија кон родниот дом. Желбата да се има дел од тој дом, желбата да се има во наследство барем парче од родниот имот, се поврзува со желбата да се има дел што те поврзува со минатото, со родителите, со младоста, односно за да може да се зачуваат родните корени. Тука преовладува сентименталното чувство за еден живот што го имала жената во младоста и на некој начин е отргнат од неа. Желбата да има едно парче значи да останат спомените на тоа време.

Кај младата генерација жени се јавува чувството, пред сѐ, на свесност за своите права, свесност за својата иднина. Како најголема причина за потреба на дел од имотот го наведуваат материјалниот фактор, кој пак придонесува за сигурна иднина. Чувството на носталгија кон родниот дом е изоставено. Како најголема причина се јавуваат социоекономските промени, кои настануваат во општеството. Сега е побитно да се има сигурна иднина бидејќи како што кажаа моите млади соговорнички: „Не знаеме што нѐ чека“.

\section{ЛИТЕРАТУРА}

АШТАЛКОВСКА, А. (2005). Патријархатот $е$ виновен за сѐ. Скопје: ЕтноАнтропоЗум, бр. 5, 171-187.

МИЛАДИНОВЦИ, К. и Д. (1962). Скопје: Кочо Рацин.

ПЕТРЕСКА, В. (2005). Урбано-руралните врски во сродничките односи. Скопје: ЕтноАнтропоЗум бр. 5, 286-323.

БОРБЕВИЋ, Ј. (2001). Сроднички односи у Врағу. Београд: Српска академија на наука и уметности, Етнографски институт, Посебна издања, књига 45.

БОРБЕВИЋ, Ј. (2005). Полна припадност и наслеђивање. Београд: Гласник етнографског института, Српске академије науке и уметности, 213-221.

\section{Извори}

Сопствени теренски истражувања реализирани во Горни села - Скопско и населбите во општина Аеродром, во периодот од 27.08. до 20.10.2017 година. 


\section{Соговорници}

Вида, родена 1955 год. во с. Нова Брезница, мажена и живее во с. Нова Брезница.

Грујоска Божа, родена 1951 год. с. Нова Брезница, мажена и живее во с. Нова Брезница.

Китановска Цанка, родена 1956 год. во с. Нова Брезница, мажена и живее во с. Нова Брезница.

Костадиновска Ана, родена 1993 год. во нас. Лисиче.

Костадиновска Верка, родена 1957 год. во Агино Село, Кумановско, мажена и живее во нас. Лисиче.

Савеска Јованка, родена 1951 год. во с. Нова Брезница, живее во нас. Лисиче.

Серафимовска Драгана, родена 1937 год. во Катлановско Блаце, живее во нас. Лисиче од 1956 год.

Трајковска Благујна, родена 1947 год. во с. Нова Брезница, живее во н. Лисиче.

Угриновска Наташа, родена 1993 год. во нас. Лисиче.

Nade Kostadinovska-Spasenovska

\section{GIVING UP THE INHERITANCE FROM WOMEN'S PERSPECTIVE} (REASONS, CONSEQUENCES, FEELINGS)

\section{Summary}

In Macedonia, according to the common law, the son is the one who inherits the propertyof the deceased parents, although in the Macedonian legislation sons and daughters are considered equal heirs of the inheritance of their parents. In practice it was traditionally expected for the daughter to give up her part of the inheritance on the account of her brother.

Women usually did that, especially in the past times. The sister would have given up her part of the inheritance out of the love for her brother, the respect for her parents and because she wanted to maintain the tradition. As obedient daughter and sister, she never gave any consideration of her own needs, feelings, and her personality. All that mattered to her was keeping up good family relations.

In the course of time the society has changed considerably and new generations of women began to emerge. These women started to think differently about the common low regarding inheritance. Nowadays, the women are not ready to give up their part of the inheritance as their ancestors did. They are becoming more and more aware of their own needs and their personality. 